\title{
DESIRE AT RISK: QUEER RECONFIGURATIONS OF SEXUAL- ITY AND RACE IN CONTEMPORARY FLOOD NARRATIVES
}

\author{
Isabel Hoving \\ University of Leiden, Netherlands
}

\section{Abstract}

Jacques Rancière's philosophical critique of Lyotard's notion of the sublime, enriched with crucial insights from dark ecology (Timothy Morton) and queer ecology, helps us to find out if, and under what conditions, the reading of nature as non-semiotic material alterity can be politically effective. To explore the different ways in which environmental collapse is being heard, this paper will consider two unusual art works, that all stage a tension between political/ethical and material readings of the flood: Craig Thompson's recent graphic novel Habibi (2011) in which a reworked orientalism is employed to propose a political and ethical reading of the flood; and After the Deluge, a visual essay by Kara Walker created after Katrina, in which race places a crucial role (2007). It is especially the latter work that shows that art can only be politically relevant when it addresses the exclusionary differentiation between intelligible media and senseless noise, such as the abject, slimy muck left behind after the flood.

Keywords: Flood Narratives, Effective-Reading Nature, Craig Thompson's Habibi, Kara Walker's After the Deluge.

\author{
EL DESEO EN RIESGO: RECONFIGURACIONES QUEER DE LA SEXUALIDAD \\ Y LA RAZA EN LAS NARRATIVAS CONTEMPORÁNEAS DEL DILUVIO
}

\section{RESUMEN}

La crítica filosófica de Jacques Rancière sobre la noción de lo sublime de Lyotard, aderezada con apuntes cruciales provenientes de la ecología oscura (Timothy Morton) y la ecología queer, nos ayudará a descubrir si, y en qué condiciones, la lectura de la naturaleza como alteridad material no-semiótica puede devenir políticamente efectiva. Para explorar las diferentes formas en las que el colapso ambiental puede ser oído, este artículo va a estudiar dos obras artísticas inusuales, que en sí mismas representan la tensión entre lecturas materiales y ético/políticas del diluvio: la novela gráfica reciente de Craig Thompson, Habibi (2011) en la que un orientalismo reelaborado se emplea para proponer una una lectura política y ética del diluvio; y After the Deluge, un ensayo visual de Kara Walker creado tras el Katrina, en el que la raza es crucial (2007). Es especialmente éste último el que muestra que el arte es políticamente relevante solo cuando aborda la diferenciación exclusiva entre los medios inteligibles y el ruido sin sentido, como es el abyecto y viscoso fango que queda tras el diluvio. Palabras clave: narrativas del diluvio, lectura efectiva de la naturaleza, Habibi de Craig Thompson, After the Deluge de Kara Walker. 


\section{INTRODUCTION}

If there is one paradigmatic example of nature talking to humanity-Natura Loquens - it must be the Biblical story of the deluge. The flood was God's way of conveying a message to humanity: that "the wickedness of man was great in the earth" (Genesis 6:5). The message, however, was far from clear, and for centuries the narrative has been the subject of scholarly debate, often in the service of the legitimization of a certain social order. What exactly was the nature of man's wickedness that had to be punished? Murder (Frymer-Kensky)? Sexual transgression (Dundes)? The ecological disaster of overpopulation? Or was it no punishment after all, but a blessing? Or, finally: was it perhaps even not a message at all?

Neither floods, nor the urge to make sense of floods, are things of the past. Kara Walker's gripping visual essay After the Deluge (2007) intervenes in the contemporary debate on the meaning of inundations. It does so by presenting itself "as an attempt to understand the subconscious narratives at work when we talk about such an event" (9) - in this case, Hurricane Katrina. Conservative Christians explained Katrina as divine punishment for New Orleans for its sexual licentiousness, notably its lively gay subculture (Richards 521), but most interpretations of the disaster focused on its racial dimension. Indeed, the storm was also seen as "cleansing' the city of racial elements" (Yousaf 565). ${ }^{1}$ Walker's visual essay acknowledges these readings, but unveils older, historical patterns of endowing meaning to the event. For African Americans, the flood cannot but refer to the Middle Passage, and therefore to slavery and racist pathologies that resulted in a toxic soup (the "muck") that poisons the black soul, but is also the place of a difficult rebirth.

The debates about the meaning of floods are of great relevance to ecocritics. It is doubtlessly highly relevant to trace the worrying social and political effects of an apocalyptical interpretation of floods as divine retribution or Nature's revenge, that either leads to the end of mankind, or a rebirth. Nowadays, an apocalyptical reading may lead to apathy in the face of present-day threats, or to repressive action against supposed culprits. Ecocriticism could help to overcome such responses by revealing the unreflected discourses at work in this rhetoric, notably, its sexual and racial politics.

With the rise of materialist approaches, however, the relevance of rhetorical and discourse analysis has been disputed, and it is often suggested that ecocriticism should rather aim at re-thinking the relation between humans and the environment by confronting the overwhelming materiality of the flood, that is: its absolute, meaningless alterity. Such an approach would not only be proposed by new materialism, but it is also explored -in a different way- in Lyotard's work on the sublime.

Jacques Rancière's philosophical critique of Lyotard's notion of the sublime (related to the impossibility of representation), enriched with crucial insights from

${ }^{1}$ A character in a television series K-Ville argued (apparently expressing a silently supported view) that the storm was 'cleansing' the city of racial elements" (Yousaf 565). 
dark ecology (Morton) and feminist and queer ecology, will guide me in the finding an answer to the question if, and under what conditions, the reading of nature as material alterity can be politically effective. In the wake of Rancière, I will take into consideration the fact that the flood's sheer materiality resists representation, often leading artists who wish to evoke floods to a highly critical, self-reflective use of media. It is for this reason that I have selected two mixed-media works to support my claims.

\section{PATRIARCHAL FANTASIES AND MYTHS OF DEVIANCE}

Let me begin at the beginning, though, and offer a short discussion of the ideologies of sex, ethnicity and race that have always been at the heart of flood narratives. Scholars trace the history of the Biblical flood myth back to earlier Sumerian myths from around $2000 \mathrm{BC}$. The Babylonian texts that were based on these incomplete Sumerian texts offer the intriguing explanation that the gods wanted to destroy men because they had multiplied to the extent that the gods were disturbed by their uproar; as one of the annoyed gods has it: "The noise of mankind (has become too intense for me)/(with their uproar) I am deprived of sleep" (Frymer-Kensky 64). In this early story, the problem is ecological rather than moral or juridical: overpopulation necessitates a divine form of birth control. After the flood, the birth goddess therefore creates creatures to prevent overpopulation, such as a new type of woman who does not bear children.

The centrality of the discourse of sexuality and reproduction that we find here is supported by scholarly interpretations of these narratives as a fertility myth, tied up with Canaanite fertility rites from the middle of the second millennium BC. In the myth, the heroic god-king of fertility is castrated because of the actions of the god of death, after which a drought ensues; the narrative ends with a violent deluge, and the return of fertility (Follansbee). It has been suggested that the Canaanite vegetation god can be recognized in the hero of the Hebrew flood story, which is based on the same old traditions (Follansbee). Indeed, the god of death here does play the part of Ham, Noah's cursed son; the biblical account that Ham "saw the nakedness of his father" (Genesis 9: 22) has been read as Ham castrating his father (Babylonian Talmud, $5^{\text {th }}$ century; or, as other sources have it, committing sexual acts with or on him (Goldenberg), or having sex with his father's wife (Levenson)). As we will see, castration is also a motif in the two contemporary texts I will discuss below. In both cases it expresses the impossibility to live as a heterosexual, reproductive male in the "muck" caused by human-made flood disasters. When seen from an ecological standpoint, with the threat of overpopulation in mind, however, we can understand why the emasculation in these early myths is not necessarily represented as degradation and death. In the biblical story, though, castration is definitely a curse.

Thus, we can oppose an earlier set of Middle Eastern narratives in which overpopulation was seen as a crucial problem, and which proposed a harnessing of heterosexual reproduction to prevent disaster, to a later Jewish-Christian narrative which (perhaps self-consciously) dismissed this framing of the story (Frymer-Kensky 
68); Noah and his sons are encouraged to "(b)e fruitful and multiply, and fill the earth" (Genesis 9: 1).

Queer ecocriticism has pointed at the unreflected heteronormativity that is at the heart of such still dominant, Jewish-Christian-based definitions of a healthy environment, that would mistakenly be characterized by its fertility and boundless reproduction only, neglecting the inevitability of corruption and death (MortimerSandilands). The biblical story of the flood supports the heteronormative opinion to legitimize patriarchy. In the newly re-installed patriarchal family, the patriarch's authority is safeguarded by expelling Ham, the castrating son.

This patriarchal view of sexuality and reproduction has been problematized from other academic approaches too, for example in Alan Dundes' 1988 analysis of the flood as a male creation fantasy ("Male Myth.") He interprets the flood as the male imitation of the female means of giving birth in the discharge of amniotic fluid (170-71). The male counterpart to the amniotic fluid is urine, and in different myths the flood is indeed represented as urine (Róheim in Dundes 171) "(M)en, to repudiate women's natural procreative superiority, must 'destroy' the first creation and substitute a second creation of their own" (Dundes 172). In addition to this male fantasy of destruction, Dundes also sees a male incestuous fantasy of sexual omnipotence that concerns the period after the flood; it imagines that "male creators can engage in sexual intercourse with mothers, sisters, and daughters" (Dundes 177). Though in the story of Noah the incestuous elements are restricted to the suggestion that Ham's transgression should be understood not so much as irreverence or castration, but rather as incestuous sexual acts with his father or mother (Goldenberg, Levenson), we could consider the expulsion of Adam and Eve from paradise and the destruction of Sodom and Gomorrah as comparable myths, and understand the incestuous sex between Adam and Eve, and Lot and his daughters, in the same light. ${ }^{2}$

The transgressive nature of life after the flood does not always obey a patriarchal logic, though. In South-East Asian myths the world after the flood is often peopled by an incestuous brother-sister pair, but also by the sole female survivor, or by a woman and her $\operatorname{dog}(\operatorname{Van})$. This imagination rather suggests traces of a matriarchal past. In such stories, the flood is not necessarily seen as divine punishment, and the survivors are no patriarchal authorities, but rather social outcasts (Van). Where the cultural work of the Judeo-Christian myth is often read as the legitimatization of a re-installed, racist, patriarchal social order, the South-East Asian myths seems to

${ }^{2}$ For if incest is the original sin that has to be wiped out by the flood (which is literally the case in Genesis, as Adam and Eve are strictly speaking either father and daughter, or brother and sister; and also often so in South East Asian and Chinese myths; Dundes, Van), sexual relations after the destruction of creation are also incestuous (most explicit in South East Asian myths, but also in Genesis, if we accept Ham's sin as sexual intercourse with either his father or his mother, or if we consider the destruction of Sodom and Gomorrah as a comparable myth, and consider the incestuous sex between survivor Lot and his daughters). The post-deluge story would embody the second male fantasy. 
focus more on the overthrow of the old, and the emergence of a new social order. In these non-Semitic flood myths, the sexual desire that emerges after the flood is decidedly non-normative. Contemporary artists who want to deconstruct the patriarchal, ethnocentric and racist, heteronormative and anti-environmental scenarios of the Judeo-Christian myth may be inspired by such intercultural, premodern queerness. The graphic novel Habibi (2011) by Graig Thompson is a case in point: evoking the Biblical narrative as much as the Islamic mythological tradition, it re-imagines castration as expressing the impossibility, and undesirability, of living as a heterosexual, reproductive male in the overpopulated waste caused by masculinist greed.

\section{EVALUATING THE CRITIQUE OF MALE DESIRE IN HABIBI}

Habibi is a very explicit environmental critique of male heterosexuality. All men in the novel are rapists, and even innocent boys are defenseless against their own aggressive sexual impulses. In line with certain feminist ecocritical discourses, it is suggested that the male heterosexual desire for control, power and wealth leads to ecological disaster. The devastating flood of waste that echoes the Babylonian myth of the overpopulated world is primarily caused by the ruthless greed of the commercial corporations that built a huge dam to appropriate the region's water supplies, and sell it back in a bottled form, thus making hygienic and healthy life impossible. This is the setting of the adventures of the two protagonists: Dodola, who is married off at nine, sold into slavery until she escapes, and Ham, who is renamed Zam, a young black enslaved boy who is saved by a twelve year old Dodola when he is three, raised by her on a stranded ship in the desert -their arc of Noah- until she is abducted and brought into the sultan's harem.

The fact that Zam is black is significant. A second thread in the larger debate that this graphic novel highlights concerns the centrality of race and ethnicity in flood myths. The diversity of the relations after the flood does not only concern sexuality, but also race and ethnicity. The flood myth can even be defined as a narrative on the way in which, after the flood, different ethnicities were produced by a new couple (Van); the myth may recount how people received their different physical appearances, just as the Judeo-Christian-Islamic texts explain how the human races came into being. In the latter tradition, race is closely connected to sexuality and sexual transgression.

After a long search, and after Zam's voluntary castration to rid himself of the sexual lusts that caused other men to rape Dodola, the pair is reunited. They find themselves in an overpopulated modern world at prey of a devastating flood of waste that echoes the Babylonian myth of the overpopulated world, and in the final scene they turn their back to the phallic world that is drowning in its own toxic deluge of pollution. The meaning of this man-made flood is clear: it stems from commercial control motivated by greed. The story's ethical answer is evoked by its recurrent imagery of fluidity and running water. Most significantly, the motive is visualized in the graphic novel's self-conscious play with Arab calligraphy, an art that the author presents in a way that both expresses meaning and resists it. 
Even more significant than the narrative per se is the way in which the graphic novel reflects on its own use of different media (words, images, calligraphy). Thus, it ties in with a larger debate about representation, here taken up as the question which media are capable of making intelligible the nature of the environmental and social problems at hand. The selection of the genre of the graphic novel in which to tell this story is indicative of its main motives and themes. The graphic novel is a mixed-media genre that inevitably struggles with the relation between word and image (Horsman), and, for Thompson, these media can be seen as expressing the different positions in the environmental, sexual and racial conflict. In the key scene in which Dodola and (castrated) Zam make love for the first time, a frame explains that a man finds his (sexual) inspiration in the image, whereas a woman is inspired by the story (639). When the non-phallic man begs to be allowed to become part of Dodola's story, the novel's critique of male heterosexuality and heterosexual procreation opens the possibility for an alternative, perhaps even queer understanding of femininity and masculinity.

Thompson decided to use the Arab calligraphic tradition as the medium to let (female) word and (male) image merge into a harmonious, fluid, interconnected whole. He re-imagines the story's ecological crisis by opposing isolation to connectedness. In Habibi, masculinity, which is the cause of the ecological crisis, stands for appropriation, greed, rape, plugging up, damming, and isolation. It is expressed by the isolation of the character (alif) that not only refers to maleness, but here, in a dramatic moment in the story, also stands for the castrated man, who has renounced the possibility of reproduction. The isolation associated with masculinity means death, and in one episode it seems as if masculinity cannot escape this destiny, even if it rids itself of its capacity for reproduction and the phallic lust for appropriation. In this destructive, heterosexist universe, desire is deeply at risk.

The story's ethical answer, however, lies in the imperative to connect; this ethical response is expressed by its aesthetics of fluidity. Seeking for a non-phallic means of connection, the story suggests an alternative that is visualised through the two heroes' non-phallic sexual union: sexual pleasure does not come from penetration or the promises of reproduction, but from the breath, which is the symbol of movement itself-and embodied in Arab calligraphy.

Thompson's laudable effort to re-imagine the Judeo-Christian flood myth through the inclusion of Quranic texts and Arab culture was inspired by the wish to counter post $9 / 11$ anti-Islamic sentiments. It is also an explicit gender critique. However, the project can be, and has been, questioned.

First, Thompson's use of media, and especially the Orientalist registers he evokes, still invites an eroticizing, Orientalist male gaze, and for this the work was severely criticized (e.g. by Tasnim, associate editor of internet forum MuslimahMediaWatch, in 2011). The fact that Orientalism has been the screen for Western explorations of alternative sexualities since its emergence may be one reason why Thompson has adopted this context for his own story. However, it has been pointed out that the novel indulges in Orientalism as much as it is emancipating Arab cultures by a painstaking ethnography of Arab cultures and the Quran (Tasnim 2011). In the same vein, one might question the sexual politics that informs the 
reflection on the intertwining of image and word that characterizes calligraphy. This reflection is ultimately less powerful than it could have been. Let us consider a crucial example: the key scenes in which the protagonists surrender to sexual love. In spite of Habibi's explicit desire to bring the male visual medium and the female narrative medium into harmony, the novel does not fully succeed. In the first place, in the scenes that lead from Dodola's request to see Zam's naked body to the final moment of ecstasy, it is in the first place Dodola's naked body that is presented to the reader/viewer fetishist gaze. ${ }^{3}$ In the second place, in spite of the interweaving of images and symbols, this final sexual union is predominantly narrated in (male) images, rather than (feminine) words. In this sense, the novel does not fully succeed in accomplishing a perfect balance between image and narrative, or between the gendered conventions of seeing and responding to the gaze.

The limitations of Thompson's ambitious project to offer an alternative discourse of sex, gender and race that comes to terms with the present-day catastrophic flood seem to lie in its use of the genre itself, the mixed-media graphic novel. Thompson decided to use the Arab calligraphic tradition as his example. This tradition, however, evoked other popular imaginary traditions in the west, and the discourse of Orientalism led to the creation of eroticizing images of women, together with the stereotypical gender scripts of women as always victimized, and men as either hypersexual despots, or eunuchs. Second, Habibi is oriented towards the ideal of the fusion of counterparts, and it adopts alchemy to underline this aim, therefore proposing a counter-cultural frame to read the events.

Zam and Dodola act as each other's double: as man and woman, black and white, brother and sister, son and mother. Steering free from phallic logic, they are destined to become one, until all difference is dissolved (642). The dissolving of differences, however, is quite at odds with the productive critique of dualism articulated in queer theory, which is concerned with the multiplication of difference instead. Indeed, this incestuous dream of unification rather recalls the male incest fantasy Dundes read in the flood myth: Zam is able to have sex with the woman who is both his mother and his sister; the only difference is that this fantasy was realized after his castration.

Philosopher Jacques Rancière may help us understand the second problem. Habibi's aesthetics of mirroring and merging leads to an ethics of consensus that,

${ }^{3}$ It is a subtle imbalance. On the first three pages (of the ten that explicitly focus on the sexual encounter), we see both Zam and Dodola engaged in intimate conversation; when Zam shows his naked, mutilated body to Dodola, on her request, the reader/viewer only sees his back. The next two pages are dedicated to a presentation of Dodola's naked body (lying on her back, covering her breasts, but open to the gaze). After two pages in which Zam and Dodola are seen to embrace each other, a page with short texts follows; after that, we see a page divided in nine frames, in which the ecstatic (masturbating) naked body of Dodola is shown three times, her face once, and Zam's face only once; the other four frames show calligraphy and symbols. On the bottom of the last, heavily decorated, page out of this series we see Zam's face watching Dodola; her face and naked breasts are visible. 
as Rancière explains, leads away from a political analysis. Ecocritic and philosopher Timothy Morton makes a comparable point when he insists on the need for critical choice, instead of dreams of harmonious reconnection. The story offers no solution for the corporate greed that caused the flood of waste; instead, it leaves us with the picture of a diverse group of passers-by who merge into one undifferentiated ocean, and the rather vague invitation (in Arab letters) to love each other. ${ }^{4}$

\section{THE POLITICAL RELEVANCE OF MUCK: AFTER THE DELUGE}

I have questioned the political effectiveness of an ecological critique that articulates an ethics through aesthetical means. However, Thompson's Habibi also moves beyond its own ethics and aesthetics, by pointing at the way in which calligraphy also resists interpretation; Thompson invites us to consider Arab texts as beautiful images rather than as meaningful words. This is what MuslimahMediaWatch-editor Tasnim reads in Thompson's own comments on his use of Arabic calligraphy: "it's almost better to not see the words when you're looking at them and you can just appreciate them for their visual aesthetic, rather than have the meaning of the words get in the way" (Tasnim). Though Thompson's gendered interpretation of media makes this a questionable request (as he associates visuality with masculinity), it might be seen as leading to a possibly productive focus on materiality. The imagination of the shapeless, abject masses of waste and people plays a small, but suggestive role in Habibi. Where Thompson suggests the possibility of translating the abhorrent mass into connectedness and love, Kara Walker's visual essay After the Deluge (2007) lingers with the abject shapelessness of what she calls the "muck." This lingering allows me to reflect on the political effectiveness of her insistence on the material alterity of muck that resists a smooth appropriation in the symbolic order.

Walker's visual essay After the Deluge addresses the aftermath of Hurricane Katrina, which laid bare the structural governmental neglect of New Orleans underprivileged, often African American population. Like Habibi, After the Deluge is dedicated to unravel "a narrative of fluid symbols in which that fluidity is figurative

\footnotetext{
${ }^{4}$ My reading of Habibi can be clarified by comparing it to another novel: Belgian writer Anne Provoost published an intelligent critique of the Biblical flood myth for young adults in 2001, in which she also unraveled the racial and sexual politics in the myth. She focuses on the myth's incomprehensible aspects, especially the question: how can Ham be black, if he has the same parents as his brothers? As a response, she presents a young black woman as Ham's lover and the mother of his future children. She illegally embarks on the arc, where she embodies the positive qualities of non-monogamous, non-patriarchal sexuality. The fact that Provoost's rewriting is a verbal narrative which does not immediately reveal the characters' skin colour makes it impossible to adopt a fetishist gaze. The reader is instead invited to make sense, through detailed, difficult reading, of the weird, complex, violent circumstances from which the sanctified western constructions of race and sex have emerged. Thus, she exposes the arbitrariness of these constructions. Provoost succeeds by adopting the very medium that Craig Thompson defines as feminine-the verbal narrative.
} 
and sometimes literal" (9), aiming "to understand the subconscious narratives at work when we talk about such an event" (9). This fluidity is represented both in a highly ambivalent, and a historically specific way: the "muck" that was left by Hurricane Katrina should be understood as the racist pathology that also animated the Middle Passage, but it is at the same time (just as the Middle Passage, as postcolonial scholar Paul Gilroy argued) "the amniotic fluid" of a painful, messy rebirth. As such, it exceeds existing discourses that are all structured by tenacious historical racial categories.

After the Deluge openly struggles with the difficulties of representing the catastrophe but it does so in a highly productive way. Most often, the flood is evoked within a predominantly African American context. Partly in line with and partly in contrast to $H a b i b i$, which continually quotes Orientalist imaginary traditions of representing social oppression (in that case: sexism), After the Deluge uses existing pictures of slavery and racism in a shockingly literal way to convey the ambivalent meaning of the "muck." The book itself comments on its strategy of quoting. Clumsily typed, misspelled texts explain the insight that identities are inevitably quotes: "whatever personality (sic) I may possess is simply the collage effect of too many meaningful documentaries" (34). The meaning of these quotes, however, is far from obvious, especially when they are brought together according to the logic of the collage. Instead of organically integrating her many pictorial quotes $\left(19^{\text {th }}\right.$ century paintings of the Deep South, Turner's Slave Ship, French engravings of the Biblical flood, etc.) in a new creation -as Thompson does- Walker presents these paintings intermittently with her own often brutal black silhouettes, that picture violent, disturbing racist scenes that are given historical depth by quoted motifs from relevant historical pictorial traditions (for example tall ships). The images evoke an intense sense of conflict.

Walker's reflection on the use of media is expressed in the short text referred to above: "this History of mine [...] was not passed down orally, was in fact, unspoken. Was simply gestured [but evoke the unsettling memory of the violent past of slavery that hurt her family, IH] I I forget waht (crossed out, IH) I was saying" (35). Words and conventional images are not adequate to express the history of the "muck." Gestures may evoke some of it, but they also evoke a visual imagination of the traumatic historical space that nullifies all efforts at communication. Central to After the Deluge, then, is a sophisticated reflection on the problem of the representation of the horrifying "muck".

One might want to propose that the book can therefore be read within the context of the discussion on the ways in which art engages with the unrepresentable. The concept of the sublime is central to this reflection. In his critique of the endeavor to understand the world as a unified whole (both by emancipatory thinkers such as Habermas and by totalitarian politicians), the French philosopher Jean-François Lyotard goes back to Kant's notion of the sublime. "The sublime," Lyotard explains Kant's approach, "is a different feeling (than, for example, taste, IH). It occurs when the imagination in fact fails to present any object which could accord with a concept," such as the Idea of totality, or the absolutely powerful. "These Ideas, for which there is no possible presentation and which therefore provide no knowledge 
of reality (experience) (...) obstruct the formation and stabilisation of taste. One could call them unpresentable" (Lyotard 1992: 6).

For Lyotard, the unpresentable is at the very heart of modernist and postmodernist art genres. These genres productively problematize the realist claim that reality can be adequately represented. In contrast to this claim, modernist and postmodernist art works testify to the existence of something that exceeds representation, either in their content (modernism), or (in the case of literature) in the way in which the work is written (postmodernism) (Lyotard 1992: 7-9; Malpas 39-46). This reference to the unpresentable has a disruptive and critical function: it counters the authoritarian effort to impose one unifying grand narrative on the world, and marginalize and silence all alternative voices. It is for this reason that Lyotard suggests that the role of art is to discern and respect silenced voices (or, I would add, silenced events), rather than to design a metalanguage that would embrace them. ${ }^{5}$

"But how do we show something that cannot be seen?" asks Lyotard. "Kant himself suggests the direction to follow when he calls formlessness, the absence of form, a possible index to the unpresentable" (1992:6). Even while the context with Lyotard's discussion of Kant is completely different, the observation is relevant for an interpretation of Walker's art. Indeed, her chilling pictures abound in shapeless blots, or roughly textured backgrounds, that resonate with comparable patches and spaces in canonized historical paintings and graphic works. Far from being the unspeakable sublime, however, Walker's muck is readable. Walker's introduction, the images, and the textual comments in between evoke a complex field of significations in which muck, floods, political violence and neglect, revenge, blood, semen, slavery and the Middle Passage all come together.

In an essay about Walker's work, Bibler relates this representational strategy to three different options to make sense of Hurricane Katrina. Following Lloyd Pratt, she argues that it can be seen as example or exception, but both options are not very helpful to understand the hurricane, as they both subordinate it to our usual understanding of the world. The third option is to see the hurricane as an event. The event is a "category of analysis" that helps to forestall "the recuperation of the unknown to the known long enough" to determine the newness of the storm (508). This option comes close to Lyotard's argument that the acknowledgement that something cannot be represented has a critical function. However, I would argue that it is even more illuminating to approach Walker's explorations through Rancière's writings on the political significance of art. Rancière discusses the ways in which art can contest the dominant regime of representation. Instead of accepting that some experiences are (naturally) unrepresentable, he argues that it is the dominant regime that decides the boundaries between what is meaningful, and what is excluded from that order. These decisions are political; they determine which senses, media, genres, and forms of expression can be understood as communication, which can be seen as a speaking subject, and what gestures and sounds can be part of the public debate. It is only

\footnotetext{
${ }^{5}$ He elaborates this argument in his discussion of the different (Lyotard 1988).
} 
when art addresses this exclusionary differentiation between intelligible media and senseless noise, that it can be politically relevant. By giving meaning to shapeless blobs of muck, Walker's art brings the formless, slimy, abject chaos (Richards 557) of the "city that care forgot," and its degraded inhabitants into the public arena. There, it becomes intelligible as an oppositional voice.

Above, I pointed at the difference between Lyotard's ethical and Rancière's political approach to art. Rancière insists that the declaration of absolute otherness is political in nature. ${ }^{6}$ This view resonates with Timothy Morton's dark ecocriticism, its critique of romanticist imaginations of nature, and its proposal to see the environment as shapeless, slimy, and possibly abhorrent instead. For Morton, too, this shapeless alterity should not be framed as sublime-as Lyotard's reference to Kant would suggest-but rather be connected with the political notion of critical choice. An adequate approach to the environment should not be aiming at harmonious interconnection, or melancholy distantiation, but rather lead to the awareness that critical choices have to be made to engage in political action.

Morton is not the only ecocritical writer who questions the political usefulness of the appreciation of unrepresentable and the sublime. While Patrick D. Murphy does not explicitly address the issue of representation, he offers a useful critique of the gendered nature of the celebration of the sublime, which is still at the heart of some contemporary nature writing and ecocriticism. Murphy's main point is that the Burkean and Kantian concepts of the sublime are shaped by the masculinist and misogynist pursuit of transcendence and mastery. More importantly still, he repeats (and revises) a statement by an earlier study on the sublime that the experience of the sublime in itself will not automatically translate into responsible environmental attitudes or actions (88). In female and feminist revisionings of the sublime, the concept's gendered, radical detachment between mind and matter makes way for a much more relational understanding of nature and human beings as always already implicated in each other (89-90). Such an approach would lead to a much more progressive, socially and politically relevant environmental understanding of the relation between humans and the more-than-human world. In this sense, Murphy's critique ties in with Morton's critique of distantiation, but adding a welcome gender analysis. ${ }^{7}$ Implicitly, Murphy's work dismisses the claim of the social relevance of the insistence on the unpresentable alterity of nature.

Rancière insists on the importance of recognizing the differences between the (represented and unrepresented) parties as political conflicts, rather than as unrepresentable incommensurability. The specific temporality of Walker's visual essay ties in with the need to recognize conflict (930). Opposing the linearity of the biblical story of the flood, Walker situates the past right in the present: the

\footnotetext{
${ }^{6}$ For a lucid explanation of the disagreement between Lyotard and Rancière see Le Roy and Vandeputte.

7 Even if Murphy criticizes Morton's ignoring of both Kant's misogynism, and the feminist rewritings of Kant and the sublime (86).
} 
discourses that made slavery and segregation possible are still present, and racism is still defining the contemporary world. In contrast to Habibi, however, After the Deluge does not merge past and present imaginations into a harmonious whole. Its visual strategies bring to the fore the violent conflicts between the ugliest moments in the past, and the present; these are conflicts between all those involved -even between the victimized themselves. This conflictuous treatment of time, I would argue, is also the space of politics.

I have discussed the relevance of Walker's flood narrative with the help of Rancière to explain the way in which a reflection on the aesthetic can have a political instead of only an ethical reading. Within the field of ecocriticism, dark ecology offers a comparable analysis: instead of dreaming of harmonious connectedness, we need to acknowledge political conflicts. Queer ecology is also close to Walker's emancipation of the "muck," as it points at the essential role of rot, death, and corruption, and the futility of utopias of boundless vitality. ${ }^{8}$ Thus, it invites us to stay within the muck. Remarkably, it is especially in the direct acknowledgement of the abject materiality of the world before and after the flood, that a politically relevant response can be found. But this is so only on the condition that one is willing to also decipher the ugly social and political causes of this abjection.

Reviews sent to author: 25 February 2018

Revised paper accepted for publication: 12 July 2018

8 Walker's essay offers several weird, if not queer, imaginations of sexuality, often within the context of violence and death. There is one moment in which a queer imagination is allowed to take flight, and that is when the possibility of transcendence of the violent racist history is considered ("We Rise nearly out of our own Humanity transforming in mid air into Angels and Centaurs and Aboriginals with wings," 95). With the dismissal of the possibility of transcendence, and the inevitability of coming to terms with the present, the possibility of queering -of becoming androgynous, becoming a mythical symbol of castration, becoming animal, and becoming part of an idiosynchronized first people- is dismissed as well. Queer ecology, however, would also refuse the possibility of transcendence, and opt for the muck instead. 


\section{WORKS CITED}

Bibler, Michael P.: “The Flood Last Time: 'Muck' and the Uses of History in Kara Walker's 'Rumination' on Katrina." Journal of American Studies 44.3 (2010): 503-18.

Dundes, Alan (ed.): The Flood Myth. Berkeley: California UP, 1988.

Dundes, Alan: "The Flood as Male Myth of Creation." Dundes 167-82.

Follansbee, Eleanor: "The Story of the Flood in the Light of Comparative Semitic Mythology." Dundes 75-88.

Frymer-Kensky, Tikva: "The Atrahas Epic and Its Significance for Our Understanding of Genesis 1-9." Dundes 61-74.

Goldenberg, David M.: "What Did Ham Do to Noah?" The Words of a Wise Man's Mouth Are Gracious. Festschrift Gunter Stemberger. Ed. Mauro Perani. Walter de Gruyter: Berlin, 2005. 257-65.

Horsman, Yasco: "Breakdowns! Het naleven van de strip in grafische romans van Spiegelman, Ware en Clowes." Frame 23.1 (2010): 8-23.

Le Roy, Frederik and Vandeputte, Kathleen: "Openbaarheid en esthetiek bij Rancière. Een annotatie bijhet melancholische project van Lyotard.” Esthetica: Tijdschrift voor kunst en filosofie 2008. <http://www.estheticatijdschrift.nl/magazine/2008/artikelen/openbaarheid-en-esthetiekbij-ranci\%C3\%A8re-een-annotatie-bij-het-melancholische-> Accessed 28 January 2012.

Levenson, Jon D.: "Genesis: Introduction and Annotations." The Jewish Study Bible. Ed. Adele Berlin, Marc Zvi Brettler. Oxford: Oxford UP, 2004. 8-101.

Lyotard, Jean-François: The Differend: Phrases in Dispute. Minneapolis: University of Minnesota Press, 1988.

Lyotard, Jean-François: "Answer to the Question, What is the Postmodern?" The Postmodern Explained to Children. Sydney: Power Publications, 1992. 1-16. http://www.marginalutility. org/wp-content/uploads/2010/04/machete_reading_may1_c.pdf Accessed 28 April 2015.

Malpas, Simon: Jean-François Lyotard. London and New York: Routlegde, 2003.

Morton, Timothy: Ecology Without Nature: Rethinking Environmental Aesthetics. Cambridge, MA: Harvard UP, 2007.

Murphy, Patrick D.: "An Ecological Feminist Revisioning of the Masculine Sublime.” Revista Canaria de Estudios Ingleses 64 (2012): 79-94.

Provoost, Anne: "In the Shadow of the Arc." New York: Arthur A. Levine, 2004. Transl. of De arkvaarders. Amsterdam: Querido, 2001.

RANCIÈRE, Jacques: "The sublime from Lyotard to Schiller. Two readings of Kant and their political Significance." Radical Philosophy 126 (2004): 8-15.

Rancière, Jacques: The Politics of Aesthetics: The Distribution of the Sensible. London: Continuum, 2004.

Richards, Gary: "Queering Katrina: Gay Discourses of the Disaster in New Orleans." Journal of American Studies 44.3 (2010): 519-34.

Tasnim: “Self-Conscious Orientalism in Craig Thompson's Habibi." Muslima MediaWatch 2012. http://www.patheos.com/blogs/mmw/2011/11/self-conscious-orientalism-in-craig-thompsons-graphic-novel-habibi/. Accessed 28 January 2012. 
Thompson, Craig: Habibi. New York, Toronto: Pantheon, 2011.

VAN, Dan Nghiem: "The Flood Myth and the Origin of Ethnic Groups in Southeast Asia." The Journal of American Folklore 106.421 (1993): 304-37.

Walker, Kara: After the Deluge. New York: Rizzoli, 2007.

Yousaf, Nahem: "Regeneration through Genre: Romancing Katrina in Crime Fiction from Tubby Meets Katrina to K-Ville." Journal of American Studies 44.3 (2010): 553-71. 